$\xi=-1$

\title{
Influence of Percentage Replacement of Metakaolin on Different Concrete Types Exposed to Internal Sulphate Attack
}

\author{
Hadeel K. Awad*, Rawaa K. Aboud ${ }^{2}$, Shatha D. Mohammed ${ }^{3}$ \\ ${ }^{1}$ University of Baghdad / Department of Civil Engineering \\ ${ }^{2}$ University of Baghdad / Department of Civil Engineering \\ ${ }^{3}$ University of Baghdad / Department of Civil Engineering \\ *Corresponding author E-mail :hadeel_k_awad@yahoo.com
}

\begin{abstract}
This research presents an experimental investigation on the influence of metakaolin replacement percentage upon some properties of different concrete types. Three types of concrete were adopted (self- compacted concrete, high performance concrete and reactive powder concrete) all of high sulphate $\left(\mathrm{SO}_{3}\right)$ percentage from the fine aggregate weight, $0.75 \%$.

Three percentages of metakaolin replacement were selected to be studied (5, 7 and 10) \%. Three types of concrete properties (compressive, flexural and splitting tensile strength) were adopted to achieve better understanding for the influence of adding metakaolin..

The output results indicated that the percentage of metakaolin had a different level of positive effect on the compressive strength for both including and excluding of internal sulphate attack. This effect reached at 28 days of curing to $(11.86,10.22$ and 4.75$) \%$ in case of excluding sulphate attack and to $(13.82,11.47$ and 6.53$) \%$ in the other case for SCC, HPC and RPC respectively. It can be concluded that the effect of metakaolin in both SCC and HPC are more influence than in RPC. Splitting and flexural strength have showed a similar behavior, flexural strength increased by $(15.38,9.42$ and 5,84$) \%$ at age of 28 days when the sulphate attack is excluded, while it was (14.02, 10.66 and 4.28)\% in case of sulphate attack included for SCC,HPC and RPC respectively. The response of splitting tensile strength for both including and excluding of sulphate attack reached to $(13.03,12.95$ and 9.17$) \%$ and $(16.88,10.33$ and 6.74$) \%$ respectively for SCC, HPC and RPC.
\end{abstract}

Keywords: High performance concrete, internal sulphate attack, metakaolin, reactive powder concrete and self-compacted concrete.

\section{Introduction}

The response among sulfate and bond glue mixes, for example, mono sulfate, portlandite, and C-S-H gel is signified as sulfate assault. Gypsum, Ettringite and Thaumasite are the principle results of this response while destabilization of the C-S-H gel might be another outcome of this response.

Ihab S., 2017, has been Researched the outside and interior impact of sulfate on ordinary and elite cement. The exploratory investigation was done utilizing two sorts of concretes, sulfate opposition and customary Portland bond of $10 \%$ smoke silica and two kinds of sand of standard SO3 $=0.2 \%$ and non-standard SO3 $=1.3 \%$. The outcomes demonstrated that the hurtful impact of the inward sulfate assault was diminished if there should be an occurrence of utilizing sulfate opposition bond and the interior sulfate assault was obvious at early ages till 90 days [1].

Nothing M. furthermore, Samaa H., 2016, have been examined the obstruction of elite cement to inward sulfate assault utilizing two kinds of bond sulfate opposition and normal Portland concrete with two mineral admixture as a fractional substitution by weight of bond, for example, high reactivity metakaolin (10\%) and silica seethe ( 8 and 10$) \%$ for the two sorts of concrete. The outcomes called attention to that the lower decrease in a few properties of bond was sulfate opposition concrete, and the most decrease in compressive quality was seen at age 90 days for normal Portland bond blends and 28 days for sulfate obstruction concrete blends and this that the utilization of high reactivity metakaolin demonstrated preferred outcomes over silica seethe [2].

Tariq S. et al, 2006, has considered the impact of inner sulfate assault on the conduct of elite cement containing metakaolin as a pozzolanic material utilizing four sulfate content in fine total (0.5,1.5,2.0 and 2.5)\%. Testing the compressive quality, part quality and ultrasonic speed showed that the quality decrease was evident at early ages (under 28 days) for both superior and conventional cement, yet at later ages (over 28 days) the elite solid decrease diminished while the decrease in customary cement expanded [3].

Anusiya M. what's more, Oviya S., 2017, have made a relative between receptive powder concrete and high quality cement. The sturdiness of the embraced solid sorts was considered by estimating the loss of solid weight after outside sulfate assault to establish out that the receptive powder concrete has higher solidness than high quality cement. Different properties, for example, compressive quality, flexural quality and youthful modulus were additionally considered, every one of these properties indicated better outcomes for responsive powder concrete contrasted with high quality cement [4].

Esam M., 2013, has researched the impact of inward sulfate assault on some mechanical properties of self-compacted cement, for example, compressive quality, flexural quality and part elasticity at (28) days and (60) days individually and contrasted them and those of reference ordinary solid blend. Three sulfate content in fine total $(0.5,1$, and 1.5$) \%$ was utilized. The outcomes demon- 
strated that expanding the size of SO3 around (0.5-1.5)\% by weight of sand caused a decrease in the compressive quality, part rigidity and modulus of break by $(10-26) \%$, (9-29)\% and (14$35) \%$ at (28) days separately, while at (60) days of restoring they diminishes by $(12-51) \%,(17-30) \%$ and $(23-43) \%$ individually [5]. Hadeel K., 2017, was exhibited an investigation on the impact of utilizing two sorts of normal Portland bonds of various compound arrangement on a few properties of self-compacted concrete. A concrete substitution of high reactivity metakaolin by $(5,10$ and $15) \%$ was considered in this exploration. It was reasoned that oneself compacted concrete blends made by Saudi Arabia Common Portland bond with a synthetic organization $\mathrm{C} 3 \mathrm{~A}=7.02 \%$ demonstrates higher protection from inside sulfate assault than blends with Tasluja conventional Portland concrete of a concoction sythesis $\mathrm{C} 3 \mathrm{~A}=4.13 \%$. The outcomes likewise shown that the SCC blends containing $15 \%$ high reactivity metakaolin indicates higher protection from inner sulfate assault [6].

\section{Research significance}

The point of this examination is to discover the impact of utilizing distinctive level of metakaolin as an incomplete substitution by weight of concrete $(5,7$ and 10)\% on some mechanical properties of SCC, HPC and RPC with a researched level of sulfate content in fine total $(0.75) \%$. This rate has accomplished by including common gypsum as a fractional substitution by weight of fine total at $(7,28,60,90$ and 120) days separately.

\section{Materials}

Normal Portland bond (OPC), which is made in Iraq known as (Tassloja) has been utilized in this examination, the physical and substance properties of the utilized concrete were displayed in Table 1 as indicated by Iraqi determination IQS NO. 5/1984 [7] and ASTM C150 2007 [8]. Two sorts of regular fine total were utilized in this investigation. The first was confirms to zone two and it was utilized in all HPC and SCC blends, the reviewing of the sand is inside the Iraqi detail IQS NO.45/1984 [9] and ASTM C33 2003 [10]. Table 2 demonstrates the reviewing, physical properties and sulfate substance of the utilized fine total. The second sort of fine total was of normal fine total with an explicit gravity of 2.59 and a grain estimate appropriation extending from $(150 \mu \mathrm{m})$ to $(600 \mu \mathrm{m})$, this sort was utilized in all receptive powder concrete blends.

The regular gypsum was of an equivalent degree as the utilized fine total. The gypsum was utilized as a halfway supplanting by weight of sand with restricted rate to expand the measure of the inward sulfate in fine total from $0.26 \%$ to $0.75 \%$. The concoction piece of the utilized gypsum is recorded in Table 3.

A most extreme size of $(10 \mathrm{~mm})$ Pounded rock has been utilized as a coarse total in HPC and SCC blends. The reviewing and physical properties are inside the limit determined of Iraqi standard IQS No.45/1984 [9], as appeared in Table 4. The water utilized for both blending and relieving for every solid kind was Faucet water. High responsive metakaolin delivered by consuming mud at temperatures went between $(700-900){ }^{\circ} \mathrm{C}$. In this examination, the locally accessible mud was scorched in consuming furnace at a temperature of $700^{\circ} \mathrm{C}$ for two hour at that point left to chill off at room temperature. The Physical properties and substance structure of HRM that fulfilled to the ASTM C $618-08$ [11] are outlined in Table 5. It has been utilized as a fractional substitution of concrete in all the blends at various rates. As to smolder, Table 6 demonstrates the physical properties and synthetic arrangement which accommodates the necessities of ASTM C1240-03[12].

The kind of superplasticizer which is utilized as a concoction admixture in this examination seemed to be (SikaViscoCrete - 5930) as per ASTM C494-05[13]. The properties of the utilized superplasticizer are appeared in Table 7.
Table 1: Cement properties

\begin{tabular}{|c|c|c|c|c|}
\hline \multicolumn{2}{|c|}{ Abbreviation } & Results & $\begin{array}{l}\text { Limit of Iraqi } \\
\text { Specification } \\
\text { No. } 5[7]\end{array}$ & $\begin{array}{c}\text { Limit of } \\
\text { ASTM C150 } \\
{[8]} \\
\end{array}$ \\
\hline \multirow{9}{*}{$\begin{array}{c}\text { Chemical } \\
\text { properties } \\
\text { (\%) }\end{array}$} & $\mathrm{CaO}$ & 62.5 & - & \\
\hline & $\mathrm{SiO}_{2}$ & 21.5 & - & \\
\hline & $\mathrm{Al}_{2} \mathrm{O}_{3}$ & 4.2 & - & \\
\hline & $\mathrm{Fe}_{2} \mathrm{O}_{2}$ & 3.95 & - & \\
\hline & $\mathrm{SO}_{z}$ & 2.36 & $\begin{array}{c}\leq 2.8 \\
\text { If } \mathrm{C}_{2} \mathrm{~A} \geq 5 \%\end{array}$ & If $\begin{array}{c}\leq 3.0 \\
\mathrm{C}_{2} \mathrm{~A} \leq 8 \%\end{array}$ \\
\hline & $\mathrm{MgO}$ & 2.47 & $\leq 5.0 \%$ & $\leq 6.0 \%$ \\
\hline & L.O.I. & 2.84 & $\leq 4.0 \%$ & $\leq 3.0 \%$ \\
\hline & I.R. & 0.56 & $\leq 1.5 \%$ & $\leq 0.75 \%$ \\
\hline & L.S.F & 0.77 & $0.66-1.02$ & \\
\hline \multirow{4}{*}{$\begin{array}{c}\text { Bogue's } \\
\text { equations }\end{array}$} & $\mathrm{C}_{2} \mathrm{~S}$ & 57.11 & - & - \\
\hline & $\mathrm{C}_{2} \mathrm{~S}$ & 18.65 & - & - \\
\hline & $\mathrm{C}_{2} \mathrm{~A}$ & 4.44 & - & - \\
\hline & $\mathrm{C}_{8} \mathrm{AF}$ & 12.02 & - & - \\
\hline \multicolumn{2}{|c|}{$\begin{array}{l}\text { Setting time (Vicat's } \\
\text { method) Initial setting } \\
\text { Final setting }\end{array}$} & $\begin{array}{c}1: 32 \\
5: 53 \\
\text { hrs.:min }\end{array}$ & $\begin{array}{l}\geq 45 \min \\
\leq 10 \mathrm{hrs} .\end{array}$ & $\begin{array}{l}\geq 45 \min \\
\leq 375 \min \end{array}$ \\
\hline \multicolumn{2}{|c|}{$\begin{array}{c}\text { Compressive strength } \\
\text { (MPa) } \\
3 \text { days } \\
7 \text { days } \\
\end{array}$} & $\begin{array}{l}16.9 \\
25.5\end{array}$ & $\begin{array}{l}\geq 15 \\
\geq 23\end{array}$ & $\begin{array}{l}\geq 12 \\
\geq 19\end{array}$ \\
\hline \multicolumn{2}{|c|}{$\begin{array}{c}\text { Blaine surface area } \\
\left(\mathrm{m}^{2} / \mathrm{kg}\right)\end{array}$} & 322 & $\geq 230$ & $\geq 280$ \\
\hline \multicolumn{2}{|c|}{$\begin{array}{c}\text { Soundness } \\
\text { (Auto clave Method) } \\
\text { (\%) }\end{array}$} & 0.4 & $\leq 0.8$ & - \\
\hline
\end{tabular}

Table 2: Properties of fine aggregate

\begin{tabular}{|c|c|c|c|c|}
\hline \multicolumn{2}{|c|}{ Tests } & \multirow{2}{*}{$\begin{array}{c}\text { Passing } \\
(\%) \\
100 \\
\end{array}$} & \multirow{2}{*}{$\begin{array}{l}\text { Iraqi specifica- } \\
\text { tions No.45/1984 } \\
\text { (Zone 2)[9] } \\
100\end{array}$} & \multirow{2}{*}{$\begin{array}{c}\text { ASTM speci- } \\
\text { fication C33- } \\
{[10]} \\
100\end{array}$} \\
\hline Sieve size & 10 & & & \\
\hline$(\mathrm{mm})$ & 4.75 & 92 & $90-100$ & $95-100$ \\
\hline & 2.36 & 89 & $75-100$ & $80-100$ \\
\hline & 1.18 & 65 & $55-90$ & $50-85$ \\
\hline & 0.6 & 51 & $35-59$ & $25-60$ \\
\hline & 0.3 & 24 & $8-30$ & $5-30$ \\
\hline & 0.15 & 6 & $0-10$ & $0-10$ \\
\hline \multicolumn{2}{|c|}{$\begin{array}{l}\text { Material finer } \\
\text { than } 0.075 \mathrm{~mm}\end{array}$} & 2.6 & $\leq 5$ & $\leq 5$ \\
\hline \multicolumn{2}{|c|}{ Sulphate $\mathrm{SO}_{3}(\%)$} & 0.26 & Max. 0.5 & - \\
\hline \multicolumn{2}{|c|}{ Absorption (\%) } & 1.12 & - & - \\
\hline
\end{tabular}

Table 3: The chemical properties of the gypsum

\begin{tabular}{|c|c|}
\hline $\begin{array}{c}\text { Compound Composition } \\
\text { Percent } \%\end{array}$ & $\begin{array}{c}\text { Compound Composition } \\
\text { Percent } \%\end{array}$ \\
\hline $\mathrm{SiO}_{2}$ & 8.91 \\
\hline $\mathrm{R}_{2} \mathrm{O}_{3}$ & 2.04 \\
\hline $\mathrm{CaO}$ & 31.65 \\
\hline $\mathrm{MgO}$ & 0.87 \\
\hline $\mathrm{SO}_{3}$ & 42.4 \\
\hline $\mathrm{I} . \mathrm{R}$ & 6.78 \\
\hline
\end{tabular}

Table 4: Properties of coarse aggregate

\begin{tabular}{|c|c|c|}
\hline \multicolumn{2}{|c|}{ Table 4: Properties of coarse aggregate } \\
\hline 37.5 & Passing\% & $\begin{array}{c}\text { Limits of Iraqi specification. } \\
\text { No.45/1984 [9] }\end{array}$ \\
\hline 20 & 100 & 100 \\
\hline 10 & 100 & $95-100$ \\
\hline 4.75 & 52 & $30-60$ \\
\hline Absorption & 6 & $0-10$ \\
\hline $\mathrm{SO}_{3}$ & $0.06 \%$ & - \\
\hline Specific gravity & 2.69 & $\leq 0.1 \%$ \\
\hline
\end{tabular}

Table 5: Physical properties and chemical composition of high reactive metakaolin

\begin{tabular}{|c|c|c|}
\hline Oxide Composition & Oxide content $\%$ & $\begin{array}{c}\text { Pozzolan class N ASTM } \\
\text { C618-03[11] }\end{array}$ \\
\hline $\mathrm{SiO}_{2}$ & 54.67 & \multirow{3}{*}{$\begin{array}{l}\Sigma=89.3 \% \\
\text { Min. } 70 \%\end{array}$} \\
\hline $\mathrm{Al}_{2} \mathrm{O}_{3}$ & 33.11 & \\
\hline $\mathrm{Fe}_{2} \mathrm{O}_{3}$ & 1.52 & \\
\hline $\mathrm{MgO}$ & 0.35 & \\
\hline $\mathrm{CaO}$ & 0.42 & \\
\hline $\mathrm{SO}_{3}$ & 0.19 & Max. $4 \%$ \\
\hline
\end{tabular}




\begin{tabular}{|c|c|c|}
\hline $\mathrm{Na}_{2} \mathrm{O}$ & 0.73 & Max. $10 \%$ \\
\hline L.O.I & 3.78 & \\
\hline \multicolumn{2}{|c|}{ Physical properties } \\
\hline \multicolumn{2}{|c|}{ Fineness (Blaine) } & $1120 \mathrm{~m}^{2} / \mathrm{kg}$ \\
\hline Specific gravity & 2.59 \\
\hline \multicolumn{2}{|c|}{ Physical form } & Powder \\
\hline
\end{tabular}

Table 6: Physical properties and chemical composition of silica fume

\begin{tabular}{|c|c|c|}
\hline $\begin{array}{c}\text { Oxide } \\
\text { Composition }\end{array}$ & $\begin{array}{c}\text { Oxide } \\
\text { Content } \%\end{array}$ & $\begin{array}{c}\text { ASTM } \\
\text { C1240-03 [12] }\end{array}$ \\
\hline $\mathrm{SiO}_{2}$ & 92.73 & Min. 85\% \\
\hline $\mathrm{Al}_{2} \mathrm{O}_{3}$ & 0.18 & \\
\hline $\mathrm{Fe}_{2} \mathrm{O}_{3}$ & 0.03 & \\
\hline $\mathrm{MgO}$ & 0.02 & Max. 6\% \\
\hline $\mathrm{CaO}$ & 0.72 & $15000 \mathrm{~m} / \mathrm{kg}$ \\
\hline $\mathrm{SO}_{3}$ & 0.42 & 2.12 \\
\hline $\mathrm{K}_{2} \mathrm{O}$ & 0.07 & Powder \\
\hline L.O.I & 3.4 & Gray \\
\hline \multicolumn{2}{|c|}{ Physical properties } \\
\hline \multicolumn{2}{|c|}{ Ppecific gravity } & Color \\
\hline \multicolumn{2}{|c|}{ Physical form } & \\
\hline
\end{tabular}

Table 7: Typical properties of superplasticizer

\begin{tabular}{|c|c|}
\hline \multicolumn{1}{c|}{ (SikaViscoCrete -5930 ) } \\
\hline Borm & Viscous liquid \\
\hline Appearance & Aqueous solution of modified polycarboxlate \\
\hline Relative density & Turbid liquid \\
\hline
\end{tabular}

\section{Mix design}

A high performance concrete with a compressive strength of $50 \mathrm{MPa}$ at 28 days has been designed according to the American Method ACI 211.4R-93 [14] as shown in Table 8. The adopted mix proportion was $(1: 1.23: 2.06)$ and the optimum dosage of superplasticizer (SikaViscoCrete -5930) was 1.2 liter for each 100 $\mathrm{kg}$ of cement which was prevailed from several trail mixes.

The self-compacted concrete mix used in this study was designed accordance to EFNARC 2005/ SF1 [15]. The mix proportion is presented in Table 8 . The materials contents are revised after gaining acceptable self-compatibility by assessing fresh concrete tests.

The RPC that's considered in this study was prepared by the following ingredients: an ordinary Portland cement, fine aggregate, silica fume, superplasticizer and high reactive metakaolin. The mix proportions of the materials used are presented in Table 8.

Table 8: The mix proportions used in preparing the test specimens

\begin{tabular}{|c|c|c|c|c|c|c|c|}
\hline $\begin{array}{c}\text { Concrete } \\
\text { Mix }\end{array}$ & $\begin{array}{c}\text { kement } \\
\mathrm{kg} / \mathrm{m}^{3}\end{array}$ & $\begin{array}{c}\text { Coarse } \\
\text { aggregate } \\
\mathrm{kg} / \mathrm{m}^{3}\end{array}$ & $\begin{array}{c}\text { Fine } \\
\text { aggregate } \\
\mathrm{kg} / \mathrm{m}^{3}\end{array}$ & $\begin{array}{c}\text { Silica } \\
\text { fume } \\
\mathrm{kg} / \mathrm{m}^{3}\end{array}$ & $\begin{array}{c}\text { Water } \\
\mathrm{kg} / \mathrm{m}^{3}\end{array}$ & $\begin{array}{c}\text { metakaolin } \\
\text { by wt. of } \\
\text { cement\% }\end{array}$ & $\begin{array}{c}\mathrm{SO}_{3} \\
\%\end{array}$ \\
\hline RfeSM1 & 416.1 & 678 & 600 & - & 188.3 & 5 & 0.26 \\
\hline SM1 & 416.1 & 678 & 600 & - & 188.3 & 5 & 0.75 \\
\hline RfeSM2 & 407.34 & 678 & 600 & - & 188.3 & 7 & 0.26 \\
\hline SM2 & 407.34 & 678 & 600 & - & 188.3 & 7 & 0.75 \\
\hline RfeSM3 & 394.2 & 678 & 600 & - & 188.3 & 10 & 0.26 \\
\hline SM3 & 394.2 & 678 & 600 & - & 188.3 & 10 & 0.75 \\
\hline RfeHM1 & 484.5 & 1050.6 & 627.3 & - & 163.2 & 5 & 0.26 \\
\hline HM1 & 484.5 & 1050.6 & 627.3 & - & 163.2 & 5 & 0.75 \\
\hline RfeHM2 & 474.3 & 1050.6 & 627.3 & - & 163.2 & 7 & 0.26 \\
\hline HM2 & 474.3 & 1050.6 & 627.3 & - & 163.2 & 7 & 0.75 \\
\hline RfeHM3 & 459 & 1050.6 & 627.3 & - & 163.2 & 10 & 0.26 \\
\hline HM3 & 459 & 1050.6 & 627.3 & - & 163.2 & 10 & 0.75 \\
\hline RfeRM1 & 721.88 & - & 1200 & 200 & 190 & 5 & 0.26 \\
\hline RM1 & 721.88 & - & 1200 & 200 & 190 & 5 & 0.75 \\
\hline RfeRM2 & 697.5 & - & 1200 & 200 & 190 & 7 & 0.26 \\
\hline RM2 & 697.5 & - & 1200 & 200 & 190 & 7 & 0.75 \\
\hline RfeRM3 & 675 & - & 1200 & 200 & 190 & 10 & 0.26 \\
\hline RM3 & 675 & - & 1200 & 200 & 190 & 10 & 0.75 \\
\hline
\end{tabular}

\section{Workability of concrete}

Slump test was performed according to ASTM C143-00 [16] to adequate the workability of high performance concrete mixes as shown in Table 9, while Slump flow test, V-funnel test and L-Box test were done to check the satisfaction of workability for selfcompacted concrete mixes accordance to EFNARC 2005/ SF1[15] as shown in Table 10

Table 9: Fresh concrete test results for high performance concrete

\begin{tabular}{|c|c|}
\hline Concrete Mix & Slump (mm) \\
\hline RefHM1 & 100 \\
\hline HM1 & 99 \\
\hline RefHM2 & 98 \\
\hline HM2 & 94 \\
\hline RefHM3 & 95 \\
\hline HM3 & 90 \\
\hline
\end{tabular}

Table 10: Fresh concrete test results for self-compacted concrete

\begin{tabular}{|c|c|c|c|c|c|c|c|}
\hline \multirow[b]{2}{*}{$\begin{array}{c}\text { Concrete } \\
\text { Mix }\end{array}$} & \multicolumn{2}{|c|}{ Slump test } & \multicolumn{2}{|c|}{ V-funnel test } & \multicolumn{3}{|c|}{ L- Box test } \\
\hline & $\begin{array}{c}\text { Slump } \\
\text { flow } \\
(\mathrm{mm})\end{array}$ & $\begin{array}{l}\text { T500 } \\
\text { (sec) }\end{array}$ & $\begin{array}{l}\mathrm{TV}_{\text {min }} \\
(\mathrm{sec})\end{array}$ & $\begin{array}{l}\mathrm{TV}_{5 \min } \\
(\mathrm{sec})\end{array}$ & $\begin{array}{c}\Delta \mathrm{H} \\
(\mathrm{H} 2 / \mathrm{H} 1)\end{array}$ & $\begin{array}{c}\mathrm{T} 20 \mathrm{~cm} \\
(\mathrm{sec})\end{array}$ & $\begin{array}{r}\text { T40 cn } \\
(\mathrm{sec})\end{array}$ \\
\hline RefSM1 & 635 & & 7.43 & 9.79 & 0.93 & 1.63 & 4.67 \\
\hline SM1 & 628 & 3.01 & 11.2 & 13.8 & 0.9 & 2.35 & 6.88 \\
\hline Ref SM2 & 623 & 2.81 & 8.23 & 11.13 & 0.89 & 1.18 & 3.97 \\
\hline SM2 & 615 & 3.15 & 12.64 & 15.8 & 0.86 & 4 & 4.4 \\
\hline Ref SM3 & 612 & 2.89 & 8.94 & 14.6 & 0.87 & 3.24 & 6.17 \\
\hline SM3 & 605 & 3.27 & 13.8 & 18.93 & 0.83 & 4.7 & 10.8 \\
\hline
\end{tabular}

\section{Hardened concrete tests.}

\subsection{Compressive strength test}

The compressive strength test was made according to B.S.1881: part 116 [17] using the average of two cubes with dimensions of $(100 \times 100 \times 100) \mathrm{mm}$ for each test.

\subsection{Flexural strength test}

This test was carried out using prism specimens of dimensions $(100 \times 100 \times 400) \mathrm{mm}$ in accordance with ASTM C293, 2006 [18] on average of two prism for each test.

\subsection{Splitting tensile strength test}

The splitting tensile strength test was carried out in accordance with the ASTM C496-/C496M-11(19). Cylindrical concrete specimens with dimensions $(100 \times 200) \mathrm{mm}$ were used to attain this test.

\section{Results and discussions}

The first mechanical property that's investigated in this study was the compressive strength. The output of the adopted mixes (SCC, HPC and RPC) have showed that the percentage of metakaolin had a different level of positive effect on the compressive strength for both cases including and excluding of internal sulphate attack as shown in Tables (11,12 and 13) and Figures (1,2 and 3). This effect reached at 28 days of curing to $(11.86,10.22$ and 4.75$) \%$ in case of excluding sulphate attack and to $(13.82,11.47$ and 6.53$) \%$ in the other case for SCC, HPC and RPC respectively. It can be concluded that the effect of metakaolin in both SCC and HPC mixes is more influence than in RPC which caused by the existing of silica fume as a constitutive material in RPC since it increases the value of the compressive strength with high percent compared to the increase caused by the metakaolin in the same mix as shown in Tables (14 and 15) and Figures (4 and 5). 
The value of compressive strength for all the considered concrete mixes between the including and excluding of internal sulphate attack has showed a different percentage of reduction in its magnitude with respect to curing age. The maximum reduction in the compressive strength was gained in RPC and SCC at age of 7 days to be (6.9 and 6.5$) \%$ respectively, while it was $4.75 \%$ for HPC. This belongs to the specialty of the RPC and SCC mix proportion, which characterized by a large percentage of fine aggregate as compared to HPC mix. This reduction in the compressive strength varies with curing age, the largest amount of this reduction was concentrated tile (28) days of curing to lie between (45$55) \%$ while the difference between the including and excluding of internal sulphate attack from (90-120) days varies between (12-16)\% due to the fact that the influence of the additive material (metakaolin in all mixes) started to be significant at later ages of curing and due to the fact that the influence of the of internal sulphate attack is concentrated at earlier ages since it has a negative effect on the activity of cement hydration

Regarding the splitting and flexural strength, there was a similarity in the behavior that's caused by adding metakaolin. The flexural strength increased by $(15.38,9.42$ and 5,84$) \%$ at age of 28 days of curing when the sulphate attack is excluded, while it was (14.02, 10.66 and 4.28$) \%$ in case of sulphate attack included for SCC,HPC and RPC respectively as shown in Tables (16, 17 and 18). There was also an increase in the splitting tensile strength for both including and excluding of sulphate attack reached to $(13.03,12.95$ and 9.17$) \%$ and $(16.88,10.33$ and 6.74$) \%$ respectively for the adopting concrete types SCC, HPC and RPC as shown in Tables (19, 20 and 21).

Table 11: Compressive strength for self-compacted concrete

\begin{tabular}{|c|c|c|c|c|c|}
\hline \multirow{2}{*}{ Sample } & \multicolumn{5}{|c|}{ Compressive Strength (MPa) } \\
\cline { 2 - 6 } & 7 days & 28 days & 60 days & 90 days & 120 days \\
\hline RefSM1 & 28.8 & 35.4 & 43.3 & 52.2 & 63.9 \\
\hline SM1 & 26.93 & 33.56 & 41.44 & 50.23 & 61.60 \\
\hline RefSM2 & 29.3 & 36.6 & 44.3 & 53.4 & 65.3 \\
\hline SM2 & 27.63 & 34.97 & 42.66 & 51.67 & 63.29 \\
\hline RefSM3 & 32.3 & 39.6 & 48 & 56.9 & 69.2 \\
\hline SM3 & 30.81 & 38.20 & 46.59 & 55.41 & 67.48 \\
\hline
\end{tabular}

Table 12: Compressive strength for high performance concrete

\begin{tabular}{|c|c|c|c|c|c|}
\hline \multirow{2}{*}{ Sample } & \multicolumn{5}{|c|}{ Compressive Strength (MPa) } \\
\cline { 2 - 6 } & 7 days & 28 days & 60 days & 90 days & 120 days \\
\hline Ref HM1 & 40.3 & 50.9 & 62.7 & 74.8 & 85.3 \\
\hline HM1 & 38.39 & 48.92 & 60.53 & 72.42 & 82.67 \\
\hline RefHM2 & 42.1 & 53.2 & 64.9 & 76.6 & 87.3 \\
\hline HM2 & 40.36 & 51.43 & 62.98 & 74.55 & 85.05 \\
\hline RefHM3 & 46.2 & 56.1 & 66.8 & 77.6 & 88 \\
\hline HM3 & 44.74 & 54.53 & 65.14 & 75.84 & 86.31 \\
\hline
\end{tabular}

Table 13: Compressive strength for reactive powder concrete

\begin{tabular}{|c|c|c|c|c|c|}
\hline \multirow{2}{*}{ Sample } & \multicolumn{5}{|c|}{ Compressive Strength (MPa) } \\
\cline { 2 - 6 } & 7 days & 28 days & 60 days & 90 days & 120 days \\
\hline RefRM1 & 57.4 & 82.1 & 91.5 & 97.5 & 98.7 \\
\hline RM1 & 53.44 & 78.13 & 88.03 & 94.27 & 95.64 \\
\hline RefRM2 & 59.4 & 84.2 & 93.6 & 98.5 & 99.6 \\
\hline RM2 & 55.92 & 80.84 & 90.53 & 95.73 & 97.26 \\
\hline RefRM3 & 60.3 & 86 & 95.2 & 100.2 & 101.4 \\
\hline RM3 & 57.41 & 83.23 & 92.78 & 98.18 & 99.42 \\
\hline
\end{tabular}

Table 14: Effect of adding metakaolin on the compressive strength (sulphate attack excluding)

\begin{tabular}{|c|c|c|c|c|c|c|}
\hline \multirow{2}{*}{$\begin{array}{c}\text { Curing } \\
\text { time } \\
\text { (days) }\end{array}$} & \multicolumn{2}{|c|}{$\begin{array}{l}\text { According to Ref } \\
\text { SM1 }\end{array}$} & \multicolumn{2}{|c|}{ According to RefHM1 } & \multicolumn{2}{|c|}{ According to RefRM1 } \\
\hline & $\begin{array}{c}\text { Ref } \\
\text { SM2 } \\
\%\end{array}$ & $\begin{array}{c}\text { Ref SM3 } \\
\%\end{array}$ & $\begin{array}{c}\text { Ref HM2 } \\
\%\end{array}$ & $\begin{array}{c}\text { Ref HM3 } \\
\%\end{array}$ & $\begin{array}{c}\text { Ref RM2 } \\
\%\end{array}$ & $\begin{array}{c}\text { Ref RM3 } \\
\%\end{array}$ \\
\hline 28 & 3.39 & 11.86 & 4.52 & 10.22 & 2.56 & 4.75 \\
\hline 60 & 2.31 & 9.79 & 3.51 & 6.54 & 2.30 & 4.04 \\
\hline 90 & 2.30 & 9.00 & 2.41 & 3.74 & 1.03 & 2.77 \\
\hline 120 & 2.19 & 8.29 & 2.34 & 3.17 & 0.91 & 2.74 \\
\hline
\end{tabular}

Table 15: Effect of adding metakaolin on the compressive strength (sulphate attack including)

\begin{tabular}{|c|c|c|c|c|c|c|}
\hline \multirow{2}{*}{$\begin{array}{c}\text { Curing } \\
\text { time } \\
\text { (days) }\end{array}$} & $\begin{array}{c}\text { According to SM1 } \\
\text { (5\% Metakaolen) }\end{array}$ & \multicolumn{2}{c|}{$\begin{array}{c}\text { According to HM1 } \\
\text { (5\% Metakaolen) }\end{array}$} & \multicolumn{2}{c|}{$\begin{array}{c}\text { According to RM1 } \\
\text { (5\% Metakaolen) }\end{array}$} \\
\cline { 2 - 7 } & SM2 \% & SM3\% & HM2\% & HM3\% & RM2\% & RM3\% \\
\hline 28 & 4.21 & 13.82 & 5.14 & 11.47 & 3.47 & 6.53 \\
\hline 60 & 2.93 & 12.41 & 4.06 & 7.62 & 2.84 & 5.40 \\
\hline 90 & 2.85 & 10.30 & 2.94 & 4.72 & 1.55 & 4.15 \\
\hline 120 & 2.74 & 9.55 & 2.88 & 4.41 & 1.70 & 3.95 \\
\hline
\end{tabular}

Table 16: Flexural strength for self-compacted concrete

\begin{tabular}{|c|c|c|c|c|c|}
\hline \multirow{2}{*}{ Sample } & \multicolumn{5}{|c|}{ Flexural Strength (MPa) } \\
\cline { 2 - 6 } & 7 days & 28 days & 60 days & 90 days & 120 days \\
\hline RefSM1 & 9.7 & 11.9 & 14.4 & 17.3 & 20.6 \\
\hline SM1 & 9.08 & 11.29 & 13.78 & 16.67 & 19.87 \\
\hline RefSM2 & 10.1 & 12.4 & 15.2 & 18.4 & 21.9 \\
\hline SM2 & 9.51 & 11.83 & 14.63 & 17.80 & 21.21 \\
\hline RefSM3 & 11.4 & 13.73 & 16.4 & 19.4 & 22.7 \\
\hline SM3 & 10.50 & 12.87 & 15.40 & 18.20 & 21.40 \\
\hline
\end{tabular}

Table 17: Flexural Strength for high performance concrete

\begin{tabular}{|c|c|c|c|c|c|}
\hline \multirow{2}{*}{ Sample } & \multicolumn{5}{|c|}{ Flexural Strength (MPa) } \\
\cline { 2 - 6 } & 7 days & 28 days & 60 days & 90 days & 120 days \\
\hline RefHM1 & 13.5 & 17.1 & 20.7 & 24.8 & 28.8 \\
\hline HM1 & 12.86 & 16.44 & 19.99 & 24.01 & 27.91 \\
\hline RefHM2 & 14.01 & 17.5 & 21.6 & 26.1 & 30.6 \\
\hline HM2 & 13.43 & 16.92 & 20.97 & 25.40 & 29.81 \\
\hline RefHM3 & 15.4 & 18.71 & 22.4 & 26.6 & 31.2 \\
\hline HM3 & 14.92 & 18.19 & 21.85 & 26.00 & 30.61 \\
\hline
\end{tabular}

Table 18: Flexural Strength for reactive powder concrete

\begin{tabular}{|c|c|c|c|c|c|}
\hline \multirow{2}{*}{ Sample } & \multicolumn{5}{|c|}{ Flexural Strength (MPa) } \\
\cline { 2 - 6 } & 7 days & 28 days & 60 days & 90 days & 120 days \\
\hline RefRM1 & 19 & 27.4 & 30.3 & 32.4 & 32.8 \\
\hline RM1 & 18.6 & 26.8 & 29.8 & 32 & 32.4 \\
\hline RefRM2 & 19.7 & 28.1 & 31.3 & 33.3 & 33.9 \\
\hline RM2 & 19.2 & 27.7 & 31 & 32.5 & 33.4 \\
\hline RefRM3 & 20.4 & 29 & 32.4 & 34.2 & 34.8 \\
\hline RM3 & 19.8 & 28 & 31.7 & 33.9 & 34.3 \\
\hline
\end{tabular}

Table 19: Splitting strength for self-compacted concrete

\begin{tabular}{|c|c|c|c|c|c|}
\hline \multirow{2}{*}{ Sample } & \multicolumn{5}{|c|}{ Splitting Strength (MPa) } \\
\cline { 2 - 6 } & 7 days & $\begin{array}{c}28 \\
\text { days }\end{array}$ & $\begin{array}{c}60 \\
\text { days }\end{array}$ & 90 days & 120 days \\
\hline RefSM1 & 3.4 & 4.2 & 5.15 & 6.21 & 7.43 \\
\hline SM1 & 3.18 & 3.98 & 4.93 & 5.98 & 7.16 \\
\hline RefSM2 & 3.77 & 4.7 & 5.83 & 7.13 & 8.53 \\
\hline SM2 & 3.54 & 4.32 & 5.19 & 6.2 & 7.37 \\
\hline RefSM3 & 4.31 & 5.26 & 6.33 & 7.61 & 9 \\
\hline SM3 & 3.67 & 4.5 & 5.48 & 6.57 & 7.81 \\
\hline
\end{tabular}

Table 20: Splitting strength for high performance concrete

\begin{tabular}{|c|c|c|c|c|c|}
\hline \multirow{2}{*}{ Sample } & 7 days & 28 days & 60 days & 90 days & $\begin{array}{c}120 \\
\text { days }\end{array}$ \\
\cline { 2 - 6 } & 4.61 & 5.71 & 6.81 & 7.93 & 9.1 \\
\hline RefHM1 & 4.32 & 5.25 & 6.32 & 7.57 & 8.85 \\
\hline HM1 & 4.82 & 5.86 & 7.1 & 8.35 & 9.48 \\
\hline RefHM2 & 4.61 & 5.63 & 6.82 & 8.14 & 9.26 \\
\hline HM2 & 5.21 & 6.3 & 7.5 & 8.73 & 9.83 \\
\hline RefHM3 & 4.9 & 5.93 & 7.1 & 8.42 & 9.64 \\
\hline HM3 & \multicolumn{5}{|c|}{}
\end{tabular}

Table 21: Splitting strength for reactive powder concrete

\begin{tabular}{|c|c|c|c|c|c|}
\hline \multirow{2}{*}{ Sample } & \multicolumn{5}{|c|}{ Splitting Strength (MPa) } \\
\cline { 2 - 6 } & 7 days & 28 days & 60 days & 90 days & 120 days \\
\hline RefRM1 & 6.4 & 9.2 & 10.31 & 10.83 & 11.1 \\
\hline RM1 & 6.13 & 8.72 & 9.84 & 10.65 & 10.8 \\
\hline RefRM2 & 6.73 & 9.51 & 10.62 & 11.31 & 11.5 \\
\hline RM2 & 6.3 & 9.1 & 10.41 & 10.9 & 11.2 \\
\hline RefRM3 & 7.1 & 9.82 & 10.85 & 11.53 & 11.87 \\
\hline RM3 & 6.7 & 9.52 & 10.6 & 11.34 & 11.64 \\
\hline
\end{tabular}




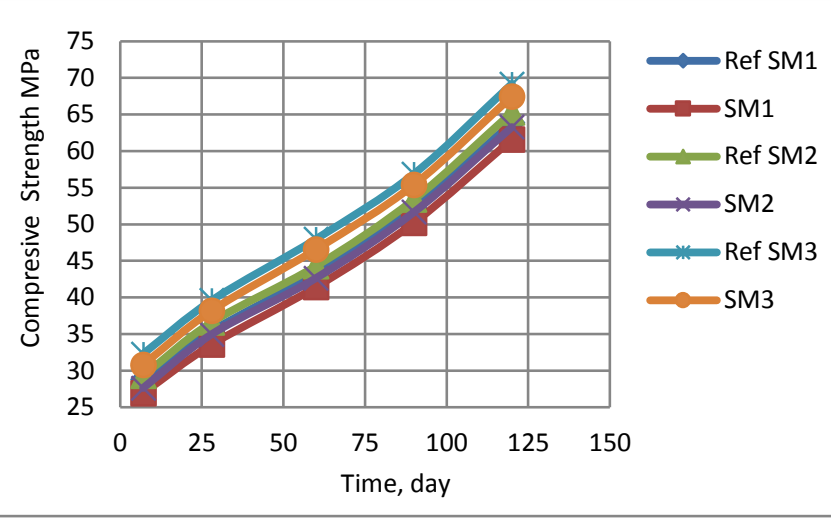

Fig.1: Compressive strength of self-compacted concrete

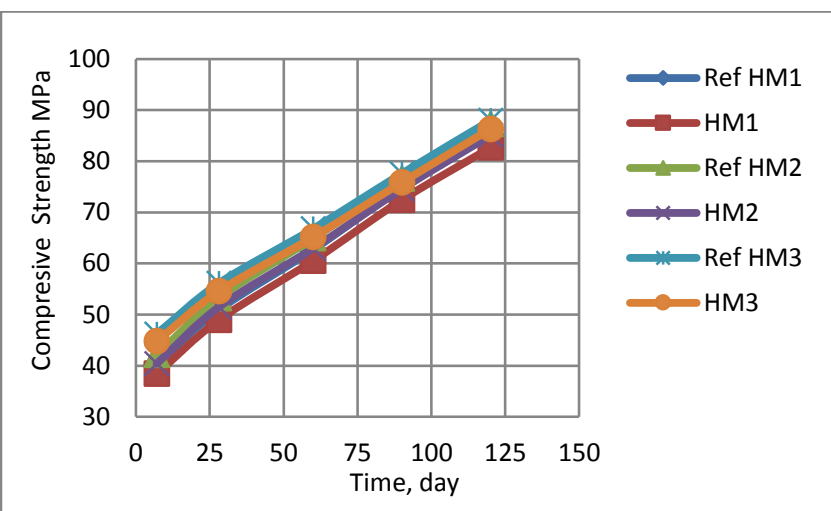

Fig. 2: Compressive strength of high performance concrete

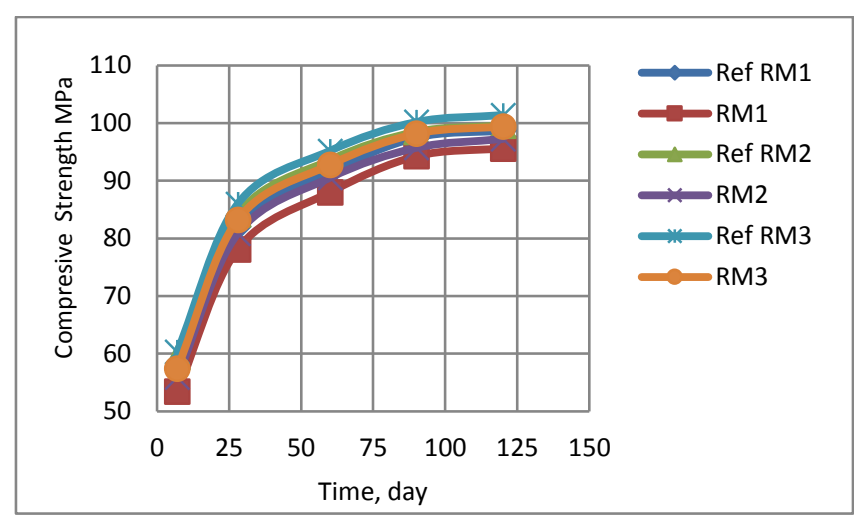

Fig. 3: Compressive strength of reactive powder concrete

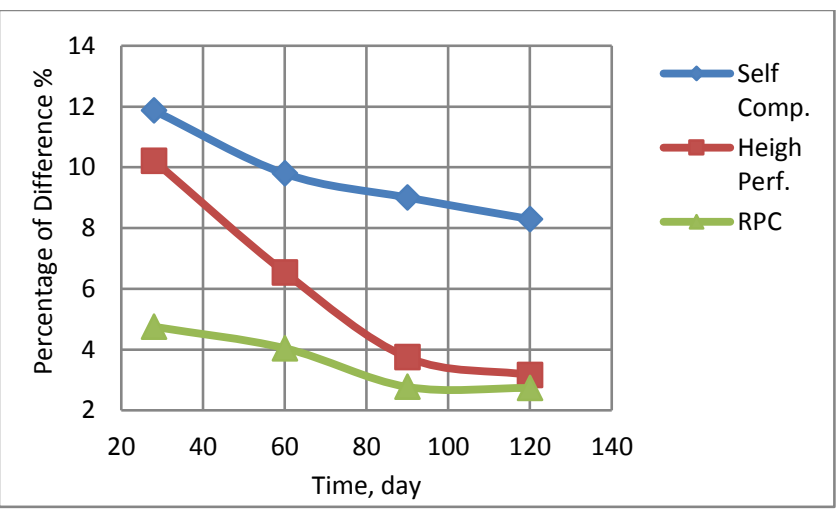

Fig. 4: Effect of adding metakaolin on the compressive strength (sulphate attack excluding)

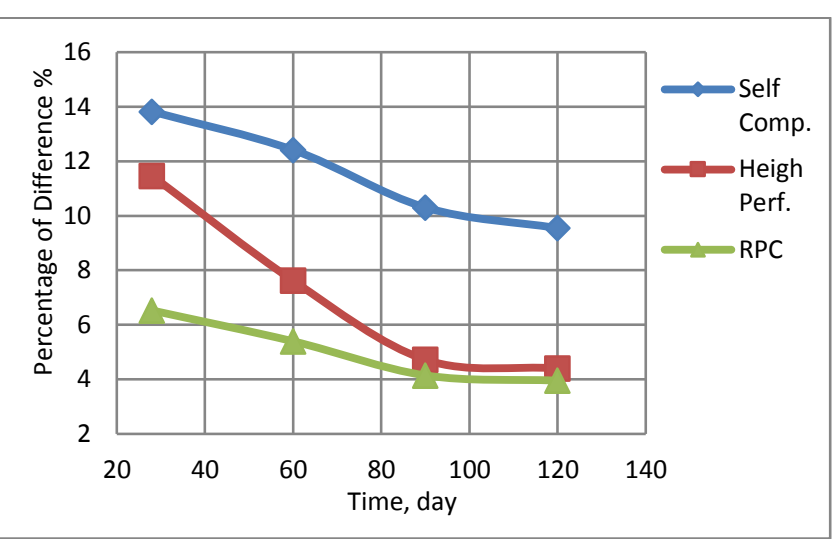

Fig. 5: Effect of adding metakaolin on the compressive strength (sulphate attack including)

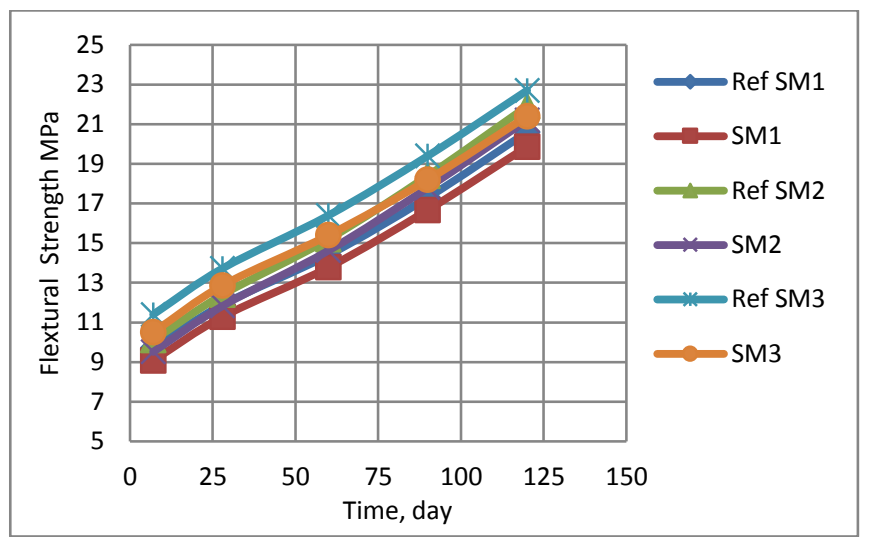

Fig. 6: Flexural strength of self-compacted concrete

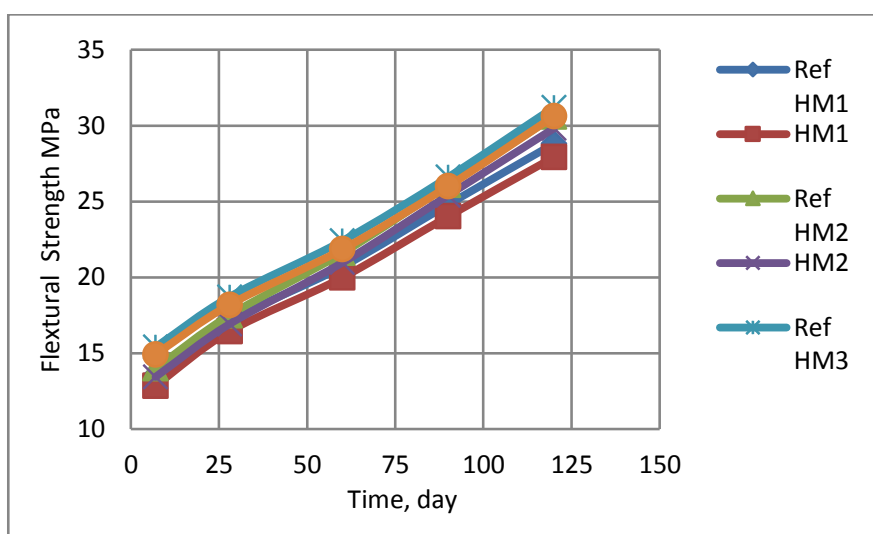

Fig. 7: Flexural strength of high performance concrete

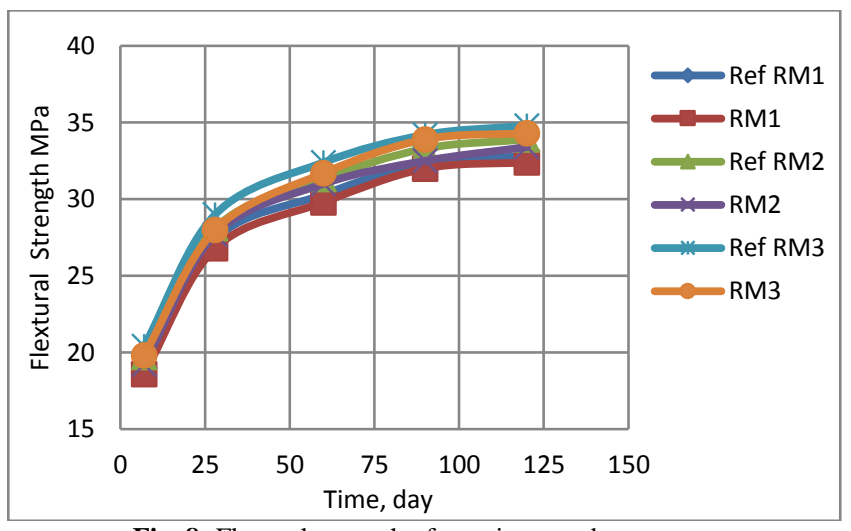

Fig. 8: Flexural strength of reactive powder concrete 


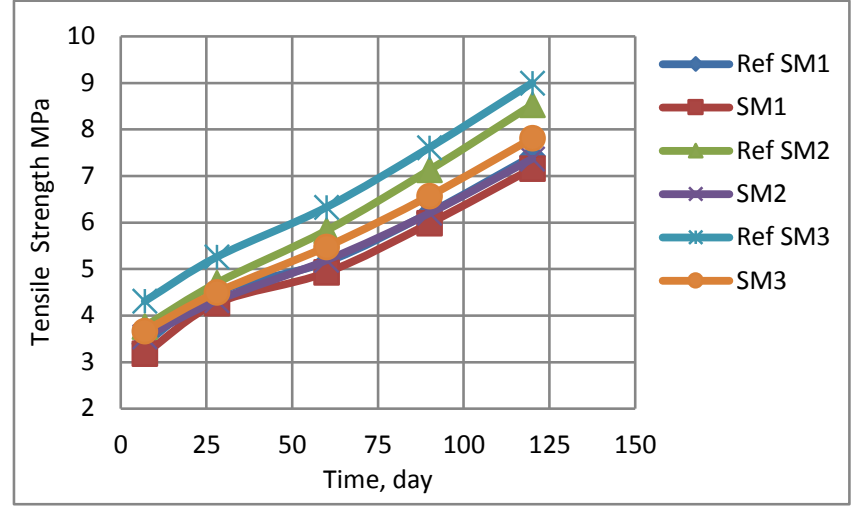

Fig. 9: Splitting tensile strength of self-compacted concrete

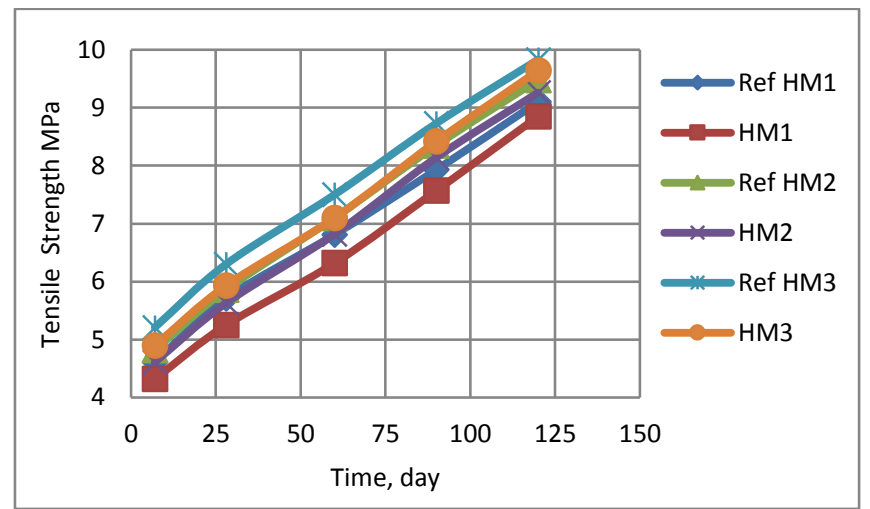

Fig. 10: Splitting tensile strength of high performance concrete

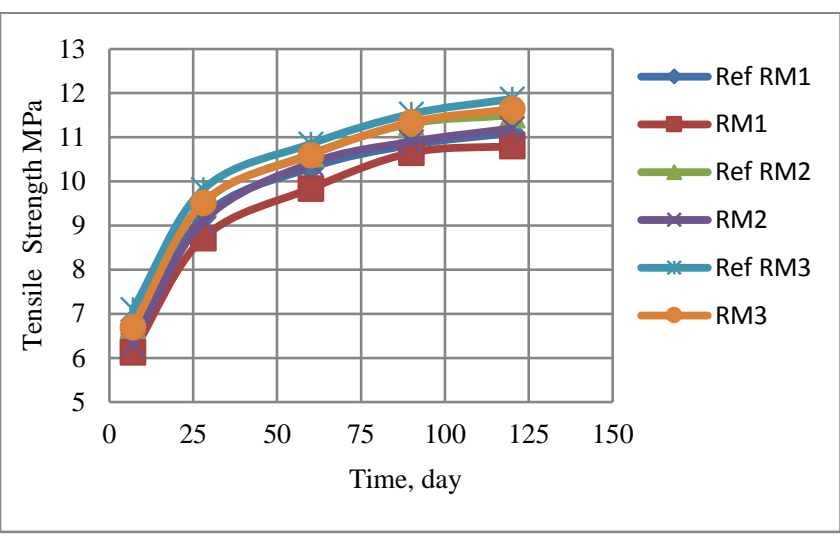

Fig. 11: Splitting tensile strength of reactive powder concrete

\section{Conclusion}

1. Adding metakaolin as a partial replacement of cement increased the efficiency of all the studied concrete types SCC, HPC and RPC since it cause a significant increase in the hardening mechanical properties (compressive, flexural and splitting tensile strength).

2. The advanced effect of metakaolin on the properties of both SCC and HPC is more efficient than in RPC.

3. Existing of internal sulphate attack reduces the positive effect of metakaolin especially for RPC and SCC since they contain a large amount of fine aggregate than in HPC.

4. The reducing in the studied mechanical properties of all the adopted concrete mixes due to the influence of internal sulphate attack was more significant in the earlier ages of curing.

\section{References}

[1] Ihab S., "Effect of External and Internal Sulphate on Compressive Strength of Concrete", International Journal of Applied Engineer- ing Research, Vol. 12, No, 20, (2017), pp. 10324-10333. https://www.ripublication.com/ijaer17/ ijaerv12n20_ 154.pdf

[2] Nada M. and Samaa A., "The Effect of Cement and Admixture Types on the Resistance of High Performance Concrete to Internal Sulphate Attack", Journal of Engineering, Vol. 22, No. 2, (2016), pp. 75-92. https://www.iasj.net/iasj?func=fulltext $\&$ aId $=107665$

[3] Tariq S., Alaa M. and Abid H.," Behavior of High Performance Concrete Exposed to Internal Sulphate Attack (GypsumContaminated Aggregate)", $10^{\text {th }}$ Biennial International Conference on Engineering, Construction, and Operations in Challenging Environments and Second NASA/ARO/ASCE Workshop on Granular Materials in Lunar and Martian Exploration, (2006).

[4] Anusiya M., Oviya S., "Comparative Study on Reactive PowderConcrete with High Strength Concrete ",International Journal of Innovative Research in Science Engineering and Technology, Vol. 6, No. 10, (2017), pp. 19868-19875. https://www.ijirset.com/upload/2017/october/125_IJIRSET\%20pap er\%20_32_.pdf

[5] Esam M., "Internal Sulphate Attack on Self Compacting Concrete", Journal of Babylon University/Engineering Sciences, Vol. 21, No. 5 , (2013), pp. 1622-1631. http://www.uobabylon.edu.iq/publications/applied_edition21/paper ed21_13.doc

[6] Hadeel K., "Influence of Internal Sulphate Attack on Some Properties of Self Compacted Concrete", Journal of Engineering, Vol. 23 , No. 5, (2017), pp. 27-46. https://www.iasj.net/iasj? func= fulltext \& aId $=124414$

[7] IQS 5-84, Iraq standard specification for Portland Cement.

[8] ASTM C150-07, Standard Specification for Portland Cement, American Society for Testing and Materials.

[9] IQS 45-84, Aggregate from natural sources for concrete and building construction.

[10] ASTM C33-03, "Standard Specifications for Concrete Aggregate", American Society for Testing and Materials.

[11] ASTM C618-08, "Standard Specification for Coal Fly Ash and Raw or Calcined Natural Pozzolan for Use in Concrete, American Society for Testing and Materials.

[12] ASTM C1240-03, "Standard Specification for Use of Silica Fume as a Mineral Admixture in Hydraulic Cement Concrete, Mortar, and Grout. American Society for Testing and Materials.

[13] ASTM C494/C494M - 05, "Standard specification for chemical admixtures for concrete", American Society for Testing and Materials.

[14] ACI Committee 211.4R, 1993, Guide for Selecting Proportions for High Strength Concrete with Portland Cement and Fly Ash.

[15] EFNARC, 2005, Specification and Guidelines for Self-Compacting Concrete, pp.32, www.efranice.org

[16] ASTM C143-00, "Standard Test Method for Slump of Hydraulic Cement Concrete". American Society for Testing and Materials.

[17] B.S.1881: part 116,"Methods for determination of compressive strength of concrete cubes", British Standard Institution, 1983.

[18] ASTM C293-06,"Standard Test Method for Flexural Strength of Concrete (Using Simple Beam with Center- Point Loading)", American Society for Testing and Materials.

[19] ASTM C496-/C496M-11, "Standard Test Method for Splitting Tensile Strength for Cylindrical Concrete Specimens", American Society for Testing and Materials. 